\title{
Simple Tube Centrifugation Method for Platelet-Rich Plasma (PRP) Preparation in Catalonian Donkeys as a Treatment of Endometritis-Endometrosis
}

\author{
Priscila Fantini ${ }^{1,2}$, Román Jiménez ${ }^{1}$, Karina Vilés ${ }^{1}\left({ }^{1}\right.$, Antoni Iborra $^{3}$, Maristela Silveira Palhares ${ }^{2}$, \\ Jaime Catalán ${ }^{1} \mathbb{D}$, Marta Prades ${ }^{1}$ and Jordi Miró ${ }^{1, * \mathbb{D}}$ \\ 1 Department de Medicina i Cirurgia Animal, Universitat Autònoma de Barcelona, \\ 08193 Cerdanyola del Vallès, Spain; fantinivet@yahoo.com.br (P.F.); romanfja@gmail.com (R.J.); \\ vileskarina@gmail.com (K.V.); dr.jcatalan@gmail.com (J.C.); marta.prades@uab.cat (M.P.) \\ 2 Departmento de Clínica e Cirurgia Veterinárias, Universidade Federal de Minas Gerais, \\ Belo Horizonte 31270-901, Brazil; maristelapalhares@gmail.com \\ 3 SCAC Servei de Cultius Cellulars i Anticossos, Universitat Autònoma de Barcelona, \\ 08193 Cerdanyola del Vallès, Spain; antoni.iborra@uab.cat \\ * Correspondence: jordi.miro@uab.cat; Tel.: +34-93-5814293
}

check for updates

Citation: Fantini, P.; Jiménez, R.; Vilés, K.; Iborra, A.; Palhares, M.S.; Catalán, J.; Prades, M.; Miró, J. Simple Tube Centrifugation Method for Platelet-Rich Plasma (PRP)

Preparation in Catalonian Donkeys as a Treatment of Endometritis-

Endometrosis. Animals 2021, 11, 2918.

https://doi.org/10.3390/ani11102918

Academic Editor:

Jean-Marie Exbrayat

Received: 6 September 2021

Accepted: 6 October 2021

Published: 9 October 2021

Publisher's Note: MDPI stays neutral with regard to jurisdictional claims in published maps and institutional affiliations.

Copyright: (c) 2021 by the authors. Licensee MDPI, Basel, Switzerland. This article is an open access article distributed under the terms and conditions of the Creative Commons Attribution (CC BY) license (https:/ / creativecommons.org/licenses/by/ $4.0 /)$.
Simple Summary: Platelet-rich plasma (PRP) is used to improve the regenerative capacity of damaged tissues in different species. In equine medicine, PRP is commonly used to treat joint diseases, tendinitis, ligamentous lesions, and persistent endometritis. Jenny endometrium shows a high sensitivity to endometritis. There are important differences between donkey and horse blood characteristics. Several protocols to obtain horse PRP have been reported, but no protocols have yet been reported for obtaining donkey PRP. Our study shows that single-spin tube centrifugation at $133 \times g$ for $10 \mathrm{~min}$ is appropriate to obtain donkey PRP with therapeutic potential in jenny endometritisendometriosis.

Abstract: The aim of this study was to standardize a simple, manual platelet-rich plasma (PRP) protocol in Catalonian donkeys using single-spin tube centrifugation as a treatment for jenny endometritis. The objective was to obtain a blood product with a moderate concentration of platelets (2 or 3 times baseline physiologic values) and a low WBC (White Blood Cells) concentration. Blood was drawn from six Catalonian donkeys using acid citrate dextrose (ACD) as an anticoagulant, and then processed by single centrifugation at $133 \times g$ for two different centrifugation times (10 and $15 \mathrm{~min}$ ). The PRP samples were evaluated by flow cytometry, and TGF- $\beta 1$ (Transforming Growth Factor-Beta1) concentrations were determined by enzyme-linked immunosorbent assay (ELISA). The $10 \mathrm{~min}$ centrifugation protocol resulted in a slightly greater release of TGF- $\beta 1(6044.79 \mathrm{ng} / \mathrm{mL})$, a 2.06-fold increase in platelet concentration, and a 15-fold reduction in leukocyte concentration when compared to the initial values. The 15 min centrifugation time resulted in a 2.44 -fold increase in baseline platelet concentration, a reduction in WBC count by a factor of 20, and slightly lower TGF levels (5206 ng/mL). We conclude that both protocols are adequate for the obtention of PRP, and both may have an acceptable therapeutic potential for use in this species, although this needs to be further validated.

Keywords: donkey; platelet-rich plasma (PRP); ACD; TGF- $\beta 1$

\section{Introduction}

Jenny endometrium shows high susceptibility to endometritis. Semen deposition induces an exacerbated inflammatory response, which is more pronounced than in mares [1,2]. Jenny endometritis is characterized by the presence of large amounts of polymorphonuclear neutrophils (PMNs) and eosinophils migrating to the uterine lumen, as well as increased cytokine expression $[2,3]$. 
After infection, neutrophils destroy pathogens by phagocytosis and by degranulation, producing DNA complexes that combine with nuclear and cytoplasmic proteins to form web-like extracellular structures called neutrophil extracellular traps (NETs) [4]. However, after intrauterine semen deposition, the PMN endometrial infiltration is induced by spermatozoa rather than bacteria [5]. A reduced number of spermatozoa are phagocytosed by PMNs, and most remain attached to NETs in a surrounding PMN halo [6]. NETs production is controlled by seminal plasma and represents the main sperm filter [7].

The failure of uterine drainage mechanisms in a mare can induce persistent metritis. NETs persistence has also been associated with the development of progressive fibrosis. Prostaglandins, inflammatory cytokines, and proteases found in NETs (e.g., elastase (ELA), cathepsin G (CAT), and myeloperoxidase (MPO)) act as pro-fibrotic factors in equine endometrial fibrosis by inducing collagen type I (COL1) accumulation [4,8-10].

Despite endometrial susceptibility, jenny endometritis seems to have its specific particularities, especially in the progression towards endometriosis. Inflammatory cells such as PMNs and eosinophils differ in timing and abundance, and there are also significant differences in the collagen distribution between jenny and mare [11].

Platelet-rich plasma is a platelet concentrate product that has been proposed as an essential agent to improve the regenerative capacity of damaged tissues [12], especially in the sub-acute phase of inflammation. Manual PRP preparation is fairly simple and inexpensive and consists of drawing whole blood in tubes with anticoagulants, then centrifuging the samples to obtain a greater concentration of platelets [13-15]. Because there are many different protocols used both in the human and veterinary literature and a lack of standardization in the realm of publications, the efficacy and treatment results are difficult to compare. Recently, Segabinazzi et al. [16] compared three different protocols to prepare equine PRP, obtaining no significant differences between one and two centrifugations, but did obtain a reduced platelet recovery using simple sedimentation. In the field of equine veterinary medicine, PRP is commonly used to treat degenerative joint diseases [17,18], tendinitis [19], ligamentous lesions [20,21], and persistent mating-induced endometritis (PMIE) [16,22,23].

Some of the most interesting molecules in PRP are the growth factors located within the platelet alpha granules $(\alpha)$. These factors play an important role in the modulation of inflammation and tissue repair since they have chemotactic properties and stimulate mitosis, proliferation, cellular differentiation [24], neovascularization, and extracellular matrix deposition [13-15,25]. There are several important growth factors in PRP, including platelet-derived growth factor (PDGF), transforming growth factors beta 1 and beta 2 (TGF- $\beta 1$ and TGF- $\beta 2$ ), epidermal growth factor (EGF), vascular endothelial growth factor (VEGF), insulin-like growth factor (IGF-1), and hepatocyte growth factor (HGF) [26,27]. TGF- $\beta$ is considered a potent inflammation modulator $[14,18,28,29]$ and analgesic agent since it inhibits the expression of nuclear factors and blocks the action of pro-inflammatory metabolites [14,30]. TGF- $\beta 1$ is the most potent cytokine [31], and its concentration is used to monitor the increase in other growth factor concentrations [32].

One of the limitations of PRP is the lack of standardization of preparation. Consequently, the color, volume, and concentration of platelets, leukocytes, growth factors, and other cell types may vary from one preparation to another, which can lead to uneven and sometimes unsatisfactory clinical results [28,33-35]. It is also important to consider that blood characteristics vary according to species and breed [36]. Thus, in order to reduce the variability of the results and increase the rate of success, the PRP preparation protocol must be species-specific. There is no scientific literature available regarding PRP protocols in donkeys.

The aim of this study was to standardize a simple, manual, and inexpensive method of PRP preparation in donkeys while obtaining enough volume for the treatment of jenny endometritis-endometriosis. 


\section{Materials and Methods}

This study was approved by the Ethics and Experimentation Committee of the Universitat Autónoma de Barcelona (CEUA/UFMG protocol number 294/2013). The experimental design is explained graphically in Figure 1.

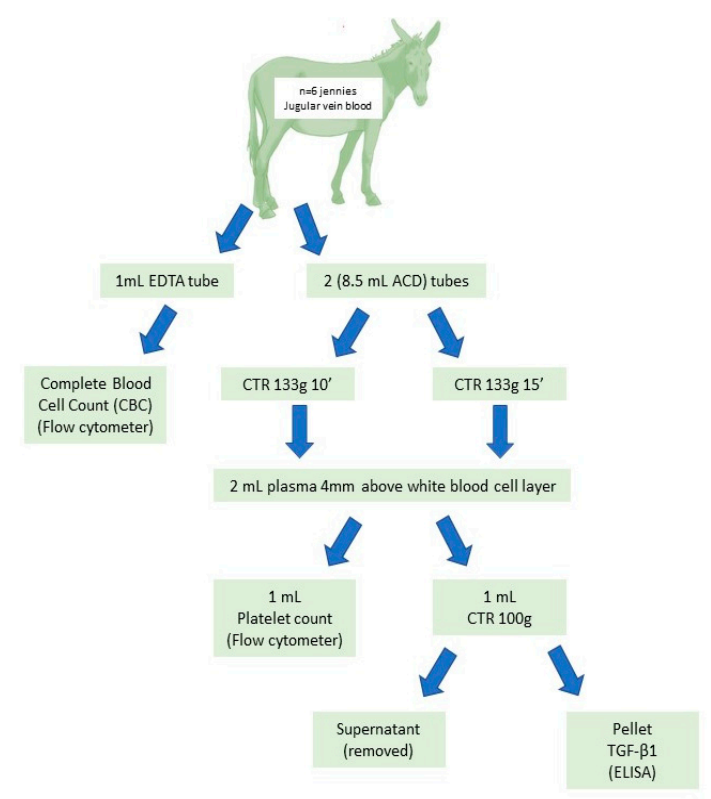

Figure 1. Experimental design.

\subsection{Animals}

Whole blood was collected from six Catalonian jennies, with ages varying from 6 to 14 years. The donkeys showed a good body condition and were clinically healthy based on physical examination and a complete blood cell analysis. Jennies were grouped in a big paddock at the Equine Reproduction Service, Autonomous University of Barcelona (Bellaterra, Cerdanyola del Vallés, Spain). Animals were fed grain forage, straw, and hay, and water was provided ad libitum.

\subsection{PRP Preparation}

The blood was collected through an aseptic puncture of the jugular vein, using a Vacutainer (Venosafe, Leuven, Belgium) system and a $23 \mathrm{G}$ needle. A sample of the blood was taken and transferred to a $1 \mathrm{~mL}$ EDTA (Ethylenediaminetetraacetic acid) tube for a complete blood cell count (CBC), while the remaining blood was transferred to two $8.5 \mathrm{~mL}$ tubes (tubes 1 and 2), containing $1.5 \mathrm{~mL}$ of ACD (Anticoagulant Citrate Dextrose solution) anticoagulant (Trisodium citrate at $22 \mathrm{~g} / \mathrm{L}$, citric acid at $8.0 \mathrm{~g} / \mathrm{L}$, and dextrose at $24.5 \mathrm{~g} / \mathrm{L}$ ) (Becton Dickinson, Franklin Lakes, NJ, USA). In sequence, the blood was homogenized manually through slow inversions of the tube.

Several preparation protocols of PRP used in horses were tested in donkeys (nonpublished data), and the most interesting results were obtained via the simple tube centrifugation method. The following protocol was selected based on reproducibility and ease of preparation. The tubes were centrifuged (CTR) at $133 \times g$ for two different centrifugation times, tube 1 being centrifuged for $10 \mathrm{~min}$ and tube 2 centrifuged for $15 \mathrm{~min}$. In each tube, $2.0 \mathrm{~mL}$ of the plasma fraction was collected in a laminar flow chamber using an $18 \mathrm{G}$ spinal needle (Becton Dickinson, Madrid, Spain). The tip of the needle was introduced until approximately $4 \mathrm{~mm}$ above the white blood cell layer (buffy coat) in order to recover the maximal number of platelets and the minimum possible amount of leukocytes.

Once the PRP was prepared, a $1.0 \mathrm{~mL}$ sample was submitted for a platelet count and evaluation by flow cytometry at the Veterinary Hematology Service of the Universitat Autònoma de Barcelona. The remaining PRP was then centrifuged at $1000 \times g$ to 
promote platelet sedimentation. After centrifugation, the supernatant was removed and immediately frozen and stored at $-20^{\circ} \mathrm{C}$. These samples were submitted for ELISA testing to determine the TGF- $\beta 1$ concentrations (SCAC, Servei de Cultius Celulars i Anticossos, Universitat Autònoma de Barcelona).

\subsection{Platelet Count and Evaluation}

Complete blood cell counts (CBCs) were performed by a hematological cytometer (ADVIA $120^{\circledR}$ Siemens Medical Solutions; Fernwald, Germany), which is a flow cytometer with two laser beams, making it possible to contrast the same value and generate accurate and reliable results. The leukocyte, erythrocyte, and platelet panels were then evaluated. The platelet parameters studied included platelet count (PLT), plateletcrit (PCT), mean platelet volume (MPV), mean platelet component concentration (MPC), platelet volume of distribution width (PDW), mean platelet dry mass (MPM), platelet dry mass distribution width (PMDW), platelet component distribution width (PCDW), concentration of large platelets (LAPLT), and platelet clumps (CLUMPS).

\subsection{Growth Factor Concentration}

TGF- $\beta 1$ (Transforming Growth Factor-Beta1) was measured by ELISA, using commercially available antibodies (DuoSet ref. DY240, Bayer Lab, New York, NY, USA). The TGF- $\beta 1$ concentration was determined using a mouse antigen-catching antibody specific for human TGF- $\beta 1$ and a biotinylated chicken detection antibody, also specific for human TGF- $\beta 1$. Human TGF- $\beta 1$ recombinant patterns were also used to elaborate the standard curve. The use of this kit in horses has already been tested and approved in previous studies of this research group [14], but its use in donkeys had not been tested. Samples were analyzed in duplicates, showing no significant differences. Observed differences were lower than previously reported in horses [14].

The samples were activated to quantify the growth factors by ELISA. This activation triggered the release of latency-associated peptides and protein disulfide isomerase (PDI) and, consequently, the formation of the inactive TGF- $\beta 1$ complex, secreted by the cells. The activation was performed in vitro by the addition of $100 \mu \mathrm{L}$ of activation buffer (acetic acid $2.5 \mathrm{~N}$ (Ref. 010.520, Sigma-Aldrich, Barcelona, Spain) and urea $10 \mathrm{M}$ (Ref. U-5128, SigmaAldrich, Barcelona, Spain) to the same volume of plasma, followed by homogenization and incubation at room temperature for $10 \mathrm{~min}$. The $\mathrm{pH}$ was neutralized with $100 \mu \mathrm{L}$ of neutralizing buffer (NaOH 2.7 M (Ref. 141687.1211, Panreac, Barcelona, Spain)/HEPES $1 \mathrm{M}$ (Ref. H3375, Sigma-Aldrich, Barcelona, Spain). We obtained different dilutions of the samples, activated with the dilution buffer (bovine serum albumin 1.4\%, Ref. 10735078001, Roche, Barcelona, Spain), Tween 20 0.05\% (Ref. 170-6531, Bio-Rad, Barcelona, Spain), in PBS (Phosphated Buffered Saline).

\subsection{Statistical Analysis}

The data were analyzed with commercial software (SPSS®Ver. 25.0 for Windows; IBM Corp., Armonk, NY, USA) and expressed as means \pm standard errors. Single-factor analysis of variance (ANOVA) was used for statistical comparisons, while the post hoc comparisons were analyzed through a Tukey's test to determine the differences between means with normal distribution, as well as variables that presented a normal distribution after $\log (x+1)$ transformation. The variables that did not present a normal distribution after the logarithmic transformation were analyzed through the Student's t-test, and the post hoc comparisons were made through the Wilcoxon test. Differences were considered statistically significant when the $p$-values were $<0.05$.

\section{Results}

\subsection{Blood Cell Count and Growth Factors Determination}

Whole blood and PRP contained different values $(p<0.05)$ of PLT, MPV, MPC, PCDW, CLUMPS, WBC White Blood Cells), RBC (Red Blood Cells), and PMN. However, there were 
no differences in these values $(p>0.05)$ between the PRPs prepared with different protocols. The TGF- $\beta 1$ concentration was greater in the protocol with a shorter centrifugation time (Table 1).

Table 1. Plasma components of whole-blood samples (EDTA) and PRP (ACD) obtained by centrifugation at $133 \times g$ for 10 and $15 \mathrm{~min}$.

\begin{tabular}{|c|c|c|c|}
\hline Variable & $\begin{array}{l}\text { Whole Blood } \\
\text { EDTA }\end{array}$ & PRP $133 \times g / 10 \mathrm{~min}$ & PRP $133 \times g / 15 \mathrm{~min}$ \\
\hline $\operatorname{PLT}\left(\times 10^{3} / \mu \mathrm{L}\right)$ & $196.66 \pm 51.42^{b}$ & $406.5 \pm 27.29^{a}$ & $479.50 \pm 75.05^{\mathrm{a}}$ \\
\hline MPV (fL) & $8.38 \pm 0.44^{b}$ & $11.25 \pm 0.27^{\mathrm{ab}}$ & $15.05 \pm 2.6^{\mathrm{a}}$ \\
\hline $\operatorname{MPC}(\mathrm{g} / \mathrm{dL})$ & $22.35 \pm 1.32^{\mathrm{a}}$ & $17.53 \pm 0.21^{\mathrm{b}}$ & $13.55 \pm 2.15^{b}$ \\
\hline PCDW $(\mathrm{g} / \mathrm{dL})$ & $7.58 \pm 0.22^{\mathrm{a}}$ & $7.16 \pm 0.1^{\mathrm{b}}$ & $5.20 \pm 1.14^{b}$ \\
\hline LAPLT $\left(\times 10^{3}\right.$ cells $\left./ \mu \mathrm{L}\right)$ & $8.161 \pm 3.29^{a}$ & $35.16 \pm 5.35^{\mathrm{a}}$ & $154.50 \pm 85.64^{\mathrm{a}}$ \\
\hline $\begin{array}{c}\text { RBCFRAG }\left(\times 10^{6}\right. \\
\text { cells } / \mu \mathrm{L})\end{array}$ & $0.02 \pm 0.006^{\mathrm{a}}$ & $0.04 \pm 0.003^{\mathrm{ab}}$ & $0.10 \pm 0.03^{\mathrm{a}}$ \\
\hline CLUMPS & $1196.83 \pm 390.15^{a}$ & $83.66 \pm 11.35^{b}$ & $89.00 \pm 38.28^{b}$ \\
\hline WBC $\left(\times 10^{3}\right.$ cells $\left./ \mu \mathrm{L}\right)$ & $10.86 \pm 0.80^{\mathrm{a}}$ & $0.74 \pm 0.16^{\mathrm{b}}$ & $0.52 \pm 0.32^{\mathrm{b}}$ \\
\hline $\mathrm{RBC}\left(\times 10^{6}\right.$ cells $\left./ \mu \mathrm{L}\right)$ & $6.56 \pm 0.25^{\mathrm{a}}$ & $0.05 \pm 0.004^{b}$ & $0.16 \pm 0.07^{b}$ \\
\hline PMN $\left(\times 10^{3}\right.$ cells $\left./ \mu \mathrm{L}\right)$ & $5.12 \pm 0.40^{\mathrm{a}}$ & $0.15 \pm 0.005^{\mathrm{b}}$ & $0.16 \pm 0.12^{b}$ \\
\hline TGF- $\beta 1(p g / m L)$ & - & $6044.79 \pm 417.91^{\mathrm{a}}$ & $5206.88 \pm 289.20^{b}$ \\
\hline PROT $(p g / m L)$ & - & $876.03 \pm 112.65^{\mathrm{a}}$ & $661.47 \pm 66.27^{\mathrm{b}}$ \\
\hline TGF:PROT & - & $14.68 \pm 1.64^{\mathrm{a}}$ & $12.79 \pm 1.25^{b}$ \\
\hline
\end{tabular}

PLT, platelet count; MPV, mean platelet volume; MPC, mean platelet component concentration; PCDW, platelet component distribution width; LAPLT, large platelets; RBCFRAG, fragments of red blood cells; CLUMPS, platelet clumps; WBC, white blood cells; RBC, red blood cells; NEU, neutrophils; TGF- $\beta 1$, transforming growth factor-beta 1 ; PROT, total protein. Different letters in the same line represent significantly different values $(p<0.05)$.

\subsection{Preliminary "In Vivo" Experience}

Two Catalonian jennies, 15 and 17 years old, with endometrial biopsies categorized as IIB in Kenney and Doig classification and presenting infertility for the last two years, were treated once. An intrauterine infusion was performed during estrus with $20 \mathrm{~mL}$ of PRP $(133 \times g$ for $10 \mathrm{~min})$ with success. The following estrus, both were inseminated and became pregnant.

\section{Discussion}

No studies were found in the literature regarding PRP preparation protocols in donkeys. This is the first study evaluating PRP preparation in donkeys, including the measurement of TGF- $\beta 1$ concentrations with different protocols. The hematological parameters of whole blood were consistent with previous parameters described for Catalonian donkeys [37]. The ADVIA $120^{\circledR}$ enabled a more accurate platelet count when compared to conventional automatized hematological analyzers, providing parameters that can be related to the activation status of the platelets. Both products showed platelet activation evidenced by an MPV (size) increase, and decreases in MPC (density) and PCDW (platelet component distribution width). The 15 min protocol showed a slight decrease in TGF- $\beta 1$ concentrations, and this is consistent with studies in other species which show that there may be variability in TGF beta yield even within the same individual at different sampling times [38].

There were no differences $(p<0.05)$ in the platelet counts between centrifugation for 10 and $15 \mathrm{~min}$. The tubes centrifuged at $133 \times g$ for $10 \mathrm{~min}$ presented a 2.06-fold increase in platelet concentration and a reduction in leukocyte concentration by a factor of 15 compared to initial values, whereas the tubes centrifuged at the same gravitational force for 15 min presented a 2.44-fold increase in platelet concentration and a 20 times reduction in leukocyte concentration. In accordance with the classification proposed by Dohan Ehrenfest et al. [39], the platelet concentrates that have 1.3 to 3 times the initial platelet value and a leukocyte concentration similar to or lower than the concentration in the whole blood are known as pure platelet-rich plasma (P-PRP). Thus, the PRP obtained can be considered a P-PRP. The mean values of platelets yielded from donkeys' blood 
were higher than the values reported in equine blood samples submitted to double tube centrifugation [14,40]. Basal donkey platelet counts are higher than those in horses [37].

In the $10 \mathrm{~min}$ protocol, platelet activation was less apparent than in samples centrifuged for $15 \mathrm{~min}$, as expressed by a lower number of CLUMPS, lower MPV, lower PCDW, and a higher MPC. However, the differences were not statistically significant $(p>0.05)$. The large individual variation, characterized by the standard error of the mean and coefficient of variation, may indicate the necessity of including a greater number of animals in future research.

It is known that the portion of the plasma with the highest platelet concentration is the $2 \mathrm{~mm}$ fraction above the buffy coat [13,27]. However, it was decided to collect the plasma fraction $4 \mathrm{~mm}$ above the buffy coat in an attempt to recover the lowest possible number of leukocytes, in order to avoid an increase in catabolic signaling molecules [41].

The higher concentration of platelet clumps in the whole blood may be due to the EDTA, since this anticoagulant is capable of producing structural and functional damage in platelets [42,43].

The higher TGF- $\beta 1$ concentration in the 10 min protocol $(p<0.05)$, even with a lower platelet concentration, may be due to the higher concentration of viable non-activated platelets in this protocol compared to the $15 \mathrm{~min}$ protocol. It is necessary to conduct more studies regarding platelet activation since, according to some authors, a higher number of viable non-activated platelets is desired [44-46] in order to have a more prolonged effect on growth factor release in time, although this has yet to be proven.

Several in vivo and in vitro experiments have shown beneficial effects of plateletrelated products in the modulation of the inflammatory process and tissue healing. To optimize PRP composition and facilitate its preparation in other species, several methods have been described. Although the literature in PRP is extensive, the lack of evidence and consensus about what method or PRP composition to use in different diseases or tissue trauma remains. In general, manual methods intended for PRP production present lower costs, but may be time-consuming and require a strict aseptic technique. Since the method described here is based on one single spin with an acceptable end product that was validated clinically in a few animals, we have provided the first step to finding the ideal product in donkeys with a method that is simple and cost-effective.

\section{Conclusions}

The methodology employed for the PRP preparation in donkeys with single tube centrifugation at $133 \times g$ for $10 \mathrm{~min}$ was appropriate to obtain supraphysiological concentrations of platelets with a significant and concurrent reduction in leukocyte content. With this protocol, the PRP also presented an acceptable concentration of TGF- $\beta 1$ as a growth factor sentinel, possibly providing enough volume and therapeutic potential for use in damaged jenny endometrium. It should be noted that there are important differences between jenny and mare endometritis and endometriosis [11], and that platelets and cytokine concentrations showed different effects (positive or adverse) in other tissues [41,47-49]. Further studies are necessary to optimize the jenny endometritis-endometriosis treatment by PRP.

Author Contributions: Conceptualization, M.P. and J.M.; methodology, P.F., R.J., A.I., and K.V.; software, P.F. and R.J.; validation, P.F., M.P. and J.M.; formal analysis, P.F., R.J., A.I. and M.S.P.; investigation, P.F., R.J., K.V., J.C. and M.S.P.; resources, M.P. and J.M.; data curation, P.F. and J.C.; writing — original draft preparation, P.F.; writing — review and editing, M.P. and J.M.; visualization, P.F. and J.C.; supervision, M.P. and J.M.; project administration, M.P. and J.M.; funding acquisition, M.P. and J.M. All authors have read and agreed to the published version of the manuscript.

Funding: This research received no external funding.

Institutional Review Board Statement: This study was approved by the Ethics and Experimentation Committee of the Universitat Autónoma de Barcelona (CEUA/UFMG protocol number 294/2013).

Informed Consent Statement: Not applicable. 
Data Availability Statement: Obtained data averages are exposed in the article.

Acknowledgments: The author is thankful to CAPES, of the Brazilian Government, for granting a scholarship to study abroad, the Equine Surgery Service and the Equine Reproduction Service at the Universitat Autònoma de Barcelona, Spain.

Conflicts of Interest: The authors declare no conflict of interest.

\section{References}

1. Miró, J.; Papas, M. Post-Artificial Insemination Endometrial Inflammation and Its Control in Donkeys. J. Equine Vet. Sci. 2018, 65, 38-43. [CrossRef]

2. Vilés, K.; Rabanal, R.; Rodríguez-Prado, M.; Miró, J. Effect of ketoprofen treatment on the uterine inflammatory response after AI of jennies with frozen semen. Theriogenology 2013, 79, 1019-1026. [CrossRef]

3. Vilés, K.; Rabanal, R.; Rodríguez-Prado, M.; Miró, J. Influence of seminal plasma on leucocyte migration and amount of COX-2 protein in the jenny endometrium after insemination with frozen-thawed semen. Anim. Reprod. Sci. 2013, 143, 57-63. [CrossRef]

4. Skarzynski, D.J.; Szóstek-Mioduchowska, A.Z.; Rebordão, M.R.; Jalali, B.M.; Piotrowska-Tomala, K.K.; Leciejewska, N.; Łazarczyk, M.; Ferreira-Dias, G.M. Neutrophils, monocytes and other immune components in the equine endometrium: Friends or foes? Theriogenology 2020, 150, 150-157. [CrossRef]

5. Kotilainen, T.; Huhtinen, M.; Katila, T. Sperm-induced leukocytosis in the equine uterus. Theriogenology 1994, 41, 629-636. [CrossRef]

6. Miró, J.; Marín, H.; Catalán, J.; Papas, M.; Gacem, S.; Yeste, M. Seminal plasma, sperm concentration, and sperm-PMN interaction in the donkey: An in vitro model to study endometrial inflammation at post-insemination. Int. J. Mol. Sci. 2020, $21,3478$. [CrossRef]

7. Mateo-Otero, Y.; Zambrano, F.; Catalán, J.; Sánchez, R.; Yeste, M.; Miro, J.; Fernandez-Fuertes, B. Seminal plasma, and not sperm, induces time and concentration-dependent neutrophil extracellular trap release in donkeys. Equine Vet. J. 2021. [CrossRef]

8. Amaral, A.; Fernandes, C.; Lukasik, K.; Szóstek-Mioduchowska, A.; Baclawska, A.; Rebordão, M.R.; Aguiar-Silva, J.; Pinto-Bravo, P.; Skarzynski, D.J.; Ferreira-Dias, G. Elastase inhibition affects collagen transcription and prostaglandin secretion in mare endometrium during the estrous cycle. Reprod. Domest. Anim. 2018, 53, 66-69. [CrossRef]

9. Amaral, A.; Fernandes, C.; Rebordão, M.R.; Szóstek-Mioduchowska, A.; Lukasik, K.; Gawronska-Kozak, B.; da Gama, L.T.; Skarzynski, D.J.; Ferreira-Dias, G. The in vitro inhibitory effect of sivelestat on elastase induced collagen and metallopeptidase expression in equine endometrium. Animals 2020, 10, 863. [CrossRef]

10. Amaral, A.; Fernandes, C.; Rebordão, M.R.; Szóstek-Mioduchowska, A.; Lukasik, K.; Pinto-Bravo, P.; da Gama, L.T.; Skarzynski, D.J.; Ferreira-Dias, G. Myeloperoxidase inhibition decreases the expression of collagen and metallopeptidase in mare endometria under in vitro conditions. Animals 2021, 11, 208. [CrossRef]

11. Miró, J.; Gutiérrez-Reinoso, M.; da Silva, J.A.; Fernandes, C.; Rebordão, M.R.; Alexandre-Pires, G.; Catalán, J.; Ferreira-Dias, G. Collagen and Eosinophils in Jenny's Endometrium: Do They Differ With Endometrial Classification? Front. Vet. Sci. $2020,7,631$. [CrossRef] [PubMed]

12. Anitua, E.; Prado, R.; Sánchez, M.; Orive, G. Platelet-Rich Plasma: Preparation and Formulation. Oper. Tech. Orthop. 2012, 22, 25-32. [CrossRef]

13. Anitua, E.; Andia, I.; Ardanza, B.; Nurden, P.; Nurden, A.T. Autologous platelets as a source of proteins for healing and tissue regeneration. Thromb. Haemost. 2004, 91, 4-15. [CrossRef] [PubMed]

14. Argüelles, D.; Carmona, J.U.; Pastor, J.; Iborra, A.; Viñals, L.; Martínez, P.; Bach, E.; Prades, M. Evaluation of single and double centrifugation tube methods for concentrating equine platelets. Res. Vet. Sci. 2006, 81, 237-245. [CrossRef] [PubMed]

15. Everts, P.A.M.; Knape, J.T.A.; Weibrich, G.; Schönberger, J.P.A.M.; Hoffmann, J.; Overdevest, E.P.; Box, H.A.M.; Van Zundert, A. Platelet-rich plasma and platelet gel: A review. J. Extra-Corpor. Technol. 2006, 38, 174-187.

16. Segabinazzi, L.G.T.M.; Podico, G.; Rosser, M.F.; Nanjappa, S.G.; Alvarenga, M.A.; Canisso, I.F. Three manual noncommercial methods to prepare equine platelet-rich plasma. Animals 2021, 11, 1478. [CrossRef]

17. Carmona, J.U.; Argüelles, D.; Climent, F.; Prades, M. Autologous Platelet Concentrates as a Treatment of Horses with Osteoarthritis: A Preliminary Pilot Clinical Study. J. Equine Vet. Sci. 2007, 27, 167-170. [CrossRef]

18. Carmona, J.U.; López, C.; Prades, M. Uso de concentrados autólogos de plaquetas obtenidos mediante el método del tubo como tratamiento de artropatías en caballos. Arch. Med. Vet. 2009, 41, 175-179. [CrossRef]

19. Argüelles, D.; Carmona, J.U.; Climent, F.; Muñoz, E.; Prades, M. Autologous platelet concentrates as a treatment for musculoskeletal lesions in five horses. Vet. Rec. 2008, 162, 208-211. [CrossRef]

20. Waselau, M.; Sutter, W.W.; Genovese, R.L.; Bertone, A.L. Intralesional injection of platelet-rich plasma followed by controlled exercise for treatment of midbody suspensory ligament desmitis in Standardbred racehorses. J. Am. Vet. Med. Assoc. 2008, 232, 1515-1520. [CrossRef]

21. Rindermann, G.; Cislakova, M.; Arndt, G.; Carstanjen, B. Autologous conditioned plasma as therapy of tendon and ligament lesions in seven horses. J. Vet. Sci. 2010, 11, 173-175. [CrossRef] 
22. Segabinazzi, L.G.; Friso, A.M.; Correal, S.B.; Crespilho, A.M.; Dell'Aqua, J.A.; Miró, J.; Papa, F.O.; Alvarenga, M.A. Uterine clinical findings, fertility rate, leucocyte migration, and COX-2 protein levels in the endometrial tissue of susceptible mares treated with platelet-rich plasma before and after AI. Theriogenology 2017, 104, 120-126. [CrossRef]

23. Dawod, A.; Miro, J.; Elbaz, H.T.; Fahmy, H.; Abdoon, A.S. Effect of intrauterine infusion of equine fresh platelets-rich plasma (Prp) or lyophilized prp (l-gfequina) on ovarian activity and pregnancy rate in repeat breeder purebred arabian mares. Animals 2021, 11, 1123. [CrossRef] [PubMed]

24. Sunitha Raja, V.; Munirathnam Naidu, E. Platelet-rich fibrin: Evolution of a second-generation platelet concentrate. Indian J. Dent. Res. 2008, 19, 42-46. [CrossRef] [PubMed]

25. Abellanet, I. La Terapia de Lesiones de Tejidos Blandos y Articulaciones con Plasma Rico en Plaquetas en Caballos de Deporte. Ph.D. Thesis, Universitat Autonòma de Barcelona, Cerdanyola del Vallès, Barcelona, Spain, 2009.

26. Anitua, E.; Andía, I.; Sanchez, M.; Azofra, J.; del Mar Zalduendo, M.; de la Fuente, M.; Nurden, P.; Nurden, A.T. Autologous preparations rich in growth factors promote proliferation and induce VEGF and HGF production by human tendon cells in culture. J. Orthop. Res. 2005, 23, 281-286. [CrossRef]

27. Weibrich, G.; Kleis, W.K.G.; Hitzler, W.E.; Hafner, G. Comparison of the platelet concentrate collection system with the plasmarich-in-growth-factors kit to produce platelet-rich plasma: A technical report. Int. J. Oral Maxillofac. Implant. 2005, 20, 118-123.

28. Dohan Ehrenfest, D.M.; Rasmusson, L.; Albrektsson, T. Classification of platelet concentrates: From pure platelet-rich plasma (P-PRP) to leucocyte- and platelet-rich fibrin (L-PRF). Trends Biotechnol. 2009, 27, 158-167. [CrossRef]

29. Yoshinaga, K.; Obata, H.; Jurukovski, V.; Mazzieri, R.; Chen, Y.; Zilberberg, L.; Huso, D.; Melamed, J.; Prijatelj, P.; Todorovic, V.; et al. Perturbation of transforming growth factor (TGF)- $\beta 1$ association with latent TGF- $\beta$ binding protein yields inflammation and tumors. Proc. Natl. Acad. Sci. USA 2008, 105, 18758-18763. [CrossRef]

30. Carmona, J.U.; Argüelles, D.; Prades, M. Niveles de factor de crecimiento transformante beta-3 y óxido nítrico en cuatro concentrados autólogos de plaquetas y plasma derivados de sangre equina. Arch. Med. Vet. 2008, 40, 155-160. [CrossRef]

31. Dohan, D.M.; Choukroun, J.; Diss, A.; Dohan, S.L.; Dohan, A.J.J.; Mouhyi, J.; Gogly, B. Platelet-rich fibrin (PRF): A secondgeneration platelet concentrate. Part I: Technological concepts and evolution. Oral Surg. Oral Med. Oral Pathol. Oral Radiol. Endodontol. 2006, 101, e37-e44. [CrossRef]

32. Visser, L.C.; Arnoczky, S.P.; Caballero, O.; Kern, A.; Ratcliffe, A.; Gardner, K.L. Growth factor-rich plasma increases tendon cell proliferation and matrix synthesis on a synthetic scaffold: An in vitro study. Tissue Eng. Part A 2010, 16, 1021-1029. [CrossRef]

33. Dohan, D.M.; Choukroun, J. PRP, cPRP, PRF, PRG, PRGF, FC ... How to find your way in the jungle of platelet concentrates? Oral Surg. Oral Med. Oral Pathol. Oral Radiol. Endodontol. 2007, 103, 305-306. [CrossRef]

34. Lei, H.; Gui, L.; Xiao, R. The effect of anticoagulants on the quality and biological efficacy of platelet-rich plasma. Clin. Biochem. 2009, 42, 1452-1460. [CrossRef]

35. Silva, A.; Sampaio, R. Anatomic ACL reconstruction: Does the platelet-rich plasma accelerate tendon healing? Knee Surg. Sport. Traumatol. Arthrosc. 2009, 17, 676-682. [CrossRef]

36. Giraldo, C.E.; López, C.; Álvarez, M.E.; Samudio, I.J.; Prades, M.; Carmona, J.U. Effects of the breed, sex and age on cellular content and growth factor release from equine pure-platelet rich plasma and pure-platelet rich gel. BMC Vet. Res. 2013, 9, 29. [CrossRef]

37. García, E. Caracterización Morfológica, Hematológica y Bioquímica Clínica en Cinco Razas Asnales Españolas Para Programas de Conservación. Ph.D. Thesis, Universitat Autònoma de Barcelona, Cerdanyola del Vallès, Barcelona, Spain, 2006.

38. Eppley, B.L.; Woodell, J.E.; Higgins, J. Platelet quantification and growth factor analysis from platelet-rich plasma: Implications for wound healing. Plast. Reconstr. Surg. 2004, 114, 1502-1508. [CrossRef]

39. Dohan Ehrenfest, D.M.; Bielecki, T.; Mishra, A.; Borzini, P.; Inchingolo, F.; Sammartino, G.; Rasmusson, L.; Evert, P.A. In Search of a Consensus Terminology in the Field of Platelet Concentrates for Surgical Use: Platelet-Rich Plasma (PRP), Platelet-Rich Fibrin (PRF), Fibrin Gel Polymerization and Leukocytes. Curr. Pharm. Biotechnol. 2012, 13, 1131-1137. [CrossRef]

40. Vendruscolo, C.P.; de Carvalho, A.M.; Moraes, L.F.; Maia, L.; Queiroz, D.L.; Watanabe, M.J.; Yamada, A.L.M.; Alves, A.L.G. Avaliação da eficácia de diferentes protocolos de preparo do Plasma Rico em Plaquetas para uso em Medicina Equina. Pesqui. Vet. Bras. 2012, 32, 106-110. [CrossRef]

41. Sundman, E.A.; Cole, B.J.; Fortier, L.A. Growth factor and catabolic cytokine concentrations are influenced by the cellular composition of platelet-rich plasma. Am. J. Sports Med. 2011, 39, 2135-2140. [CrossRef]

42. Macey, M.; McCarthy, D.; Azara, U.; Milne, T.; Golledge, P.; Newland, A. Ethylenediaminetetraacetic Acid Plus CitrateTheophylline-Adenosine-Dipyridamole (EDTA-CTAD): A Novel Anticoagulant for the Flow Cytometric Assessment of Platelet and Neutrophil Activation Ex Vivo in Whole Blood. Cytom. Part B Clin. Cytom. 2003, 51, 30-40. [CrossRef]

43. Silva, R.F.; Santana, G.C.; Leme, F.O.P.; Carmona, J.U.; Rezende, C.M.F. Release of transforming growth factor beta 1 and platelet derived growth factor type AB from canine platelet gels obtained by the tube method and activated with calcium salts. Arch. Med. Vet. 2013, 45, 159-165. [CrossRef]

44. Marx, R.E. Platelet-Rich Plasma: Evidence to Support Its Use. J. Oral Maxillofac. Surg. 2004, 62, 489-496. [CrossRef]

45. Carmona, J.U.; López, C.; Giraldo, C.E. Use of autologous platelet concentrates as regenerative therapy for chronic diseases of the equine musculoskeletal system. Arch. Med. Vet. 2011, 43, 29. [CrossRef]

46. Silva, R.F.; Rezende, C.M.F.; Paes-Leme, F.O.; Carmona, J.U. Evaluación del método del tubo para concentrar plaquetas caninas: Estudio celular. Arch. Med. Vet. 2011, 43, 95-98. [CrossRef] 
47. Boswell, S.C.; Schnabel, L.V.; Mohammed, H.O.; Sundman, E.A.; Minas, T.; Fortier, L.A. Increasing platelet concentrations in leucocyte-reduced platelet-rich plasma decrease collagen gene synthesis in tendons. Am. J. Sports Med. 2013, 42, 42-49. [CrossRef]

48. McCarrell, T.M.; Minas, T.; Fortier, L.A. Optimization of leucocyte concentration in platelet-rich plasma for the treatment of tendinopathy. J. Bone Joint. Surg. Am. 2012, 94, e143. [CrossRef]

49. McCarrell, T.M.; Mall, N.A.; Lee, A.S.; Cole, B.J.; Butty, D.C.; Fortier, L.A. Considerations for the use of platelet-rich plasma in orthopedics. Sports Med. 2014, 44, 1025-1036. [CrossRef] 